University of Nebraska - Lincoln

DigitalCommons@University of Nebraska - Lincoln

Faculty Publications: Department of

Entomology

1980

\title{
Honeydew Excretion Measurement Techniques for Determining Differential Feeding Activity of Biotypes of Nilaparvata lugens on Rice Varieties
}

\author{
P. Paguia \\ International Rice Research Institute \\ M. D. Pathak \\ International Rice Research Institute \\ E. A. Heinrichs \\ International Rice Research Institute, eheinrichs2@unl.edu
}

Follow this and additional works at: https://digitalcommons.unl.edu/entomologyfacpub

Part of the Agriculture Commons, and the Entomology Commons

\footnotetext{
Paguia, P.; Pathak, M. D.; and Heinrichs, E. A., "Honeydew Excretion Measurement Techniques for Determining Differential Feeding Activity of Biotypes of Nilaparvata lugens on Rice Varieties" (1980). Faculty Publications: Department of Entomology. 836. https://digitalcommons.unl.edu/entomologyfacpub/836
}

This Article is brought to you for free and open access by the Entomology, Department of at DigitalCommons@University of Nebraska - Lincoln. It has been accepted for inclusion in Faculty Publications: Department of Entomology by an authorized administrator of DigitalCommons@University of Nebraska - Lincoln. 


\title{
Honeydew Excretion Measurement Techniques for Determining Differential Feeding Activity of Biotypes of Nilaparvata lugens on Rice Varieties ${ }^{1,2}$
}

\author{
P. Paguia, M. D. Pathak, and E. A. Heinrichs ${ }^{3}$
}

\begin{abstract}
Techniques to quantify the feeding activity of Nilaparvata lugens (Stål) on rice varieties as based on honeydew excretion are described, and their potential as a bioassay for biotype identification are discussed. Honeydew, excreted on filter paper, was stained with ninhydrin and quantified by measuring the area $\left(\mathrm{mm}^{2}\right)$ or by weighing. Results were satisfactory but the methods were extremely tedious. Volumetric measurement of honeydew with micropipettes was less sensitive.

The color intensity of one $\mu$ liter honeydew streaked on filter paper and treated with $0.001 \%$ ninhydrin was determined with a Fujiox Densitometer. The method was relatively simple and rapid and was sufficiently precise for biotype identification as based on differential feeding activity.

Nilaparvata lugens (Stål), commonly known as the brown planthopper, is one of the most important insect pests of rice and has had a distinct economic effect on rice farmers in Asia (Dyck 1979). The hopper causes direct damage by sucking plant sap, which often results in hopperburn. It also transmits 2 virus diseases, namely, grassy stunt (Ling et al. 1970) and ragged stunt (Ling et al. 1978). Control of N. lugens has been complicated as some of the high-yielding modern varieties that carry genes for resistance have succumbed to strains or biotypes of this species which have been selected for in the field.

Studies on the genetics of resistance to $N$. lugens reveal that resistance in varieties "Mudgo," C022, and MTU15 is governed by a single dominant gene designated as Bph 1. Resistance of ASD7 was found to be due to a single recessive gene, the bph 2 gene (Khush 1979). Biotype 1, the original field population in the Philippines, can only destroy varieties having no gene for resistance. Varieties with the Bph 1 gene for resistance are susceptible
\end{abstract}


to biotype 2, and varieties with resistant bph 2 gene are susceptible to biotype 3 (Pathak and Khush 1979). Biotype 2 has become abundant in the Philippines and Indonesia where IR26 was widely grown. Biotype 3 has been selected in the greenhouse but has not yet become abundant in the field where bph 2 gene varieties have been grown for ca. 2 years.

The screening program for varietal resistance to N. lugens at the International Rice Research Institute (IRRI) has substantially increased due to the existence of the biotypes. A simple, fast, and precise bioassay technique is required for identification of resistant varieties and isolation of the 3 biotypes.

Measurement of honeydew excretion as a tool in assessing resistance and susceptibility of a variety was demonstrated by Auclair $(1958,1959)$ with the pea aphid, Acyrthosiphon pisum (Harris). For N. lugens, low honeydew excretion was related to the resistance of the rice varieties Mudgo (Sogawa and Pathak 1970), ARC5785, BKN6909-74-40, XB5, HRI2, and Ptb21 among many other tested materials (Karim 1975). It also has been demonstrated that these differences in the amount of excretion are related to differences in food intake by the insects on resistant and nonresistant varieties.

Reported here are several methods to assess honeydew excretion by N. lugens and their usefulness as a bioassay for the identification of the different biotypes.

\section{Materials and Methods}

\section{Filter Paper Method}

\section{Visual Estimates}

Honeydew excreted by $N$. lugens was collected in a feeding chamber previously developed at IRRI (Sogawa and Pathak 1970). The feeding chamber (Fig. 1) consisted of an inverted transparent plastic cup placed over a filter paper resting on a plastic petri dish. Five 2-dayold adult females previously starved for ca. $5 \mathrm{~h}$ were placed into the chamber through a hole at the top of the cup. A cotton wad was then placed in the hole to prevent escape of the insects. The insects were allowed to feed overnight and, in the morning, the filter papers were collected and treated with $0.001 \%$ ninhydrin in acetone solution. After being oven-dried for $5 \mathrm{~min}$ at $100^{\circ} \mathrm{C}$, the honeydew stains appeared as violet or purple due to their amino acid content. The feeding chambers were arranged in a randomized complete block design, each cup serving as a replicate. Each treatment was replicated 8 times. 


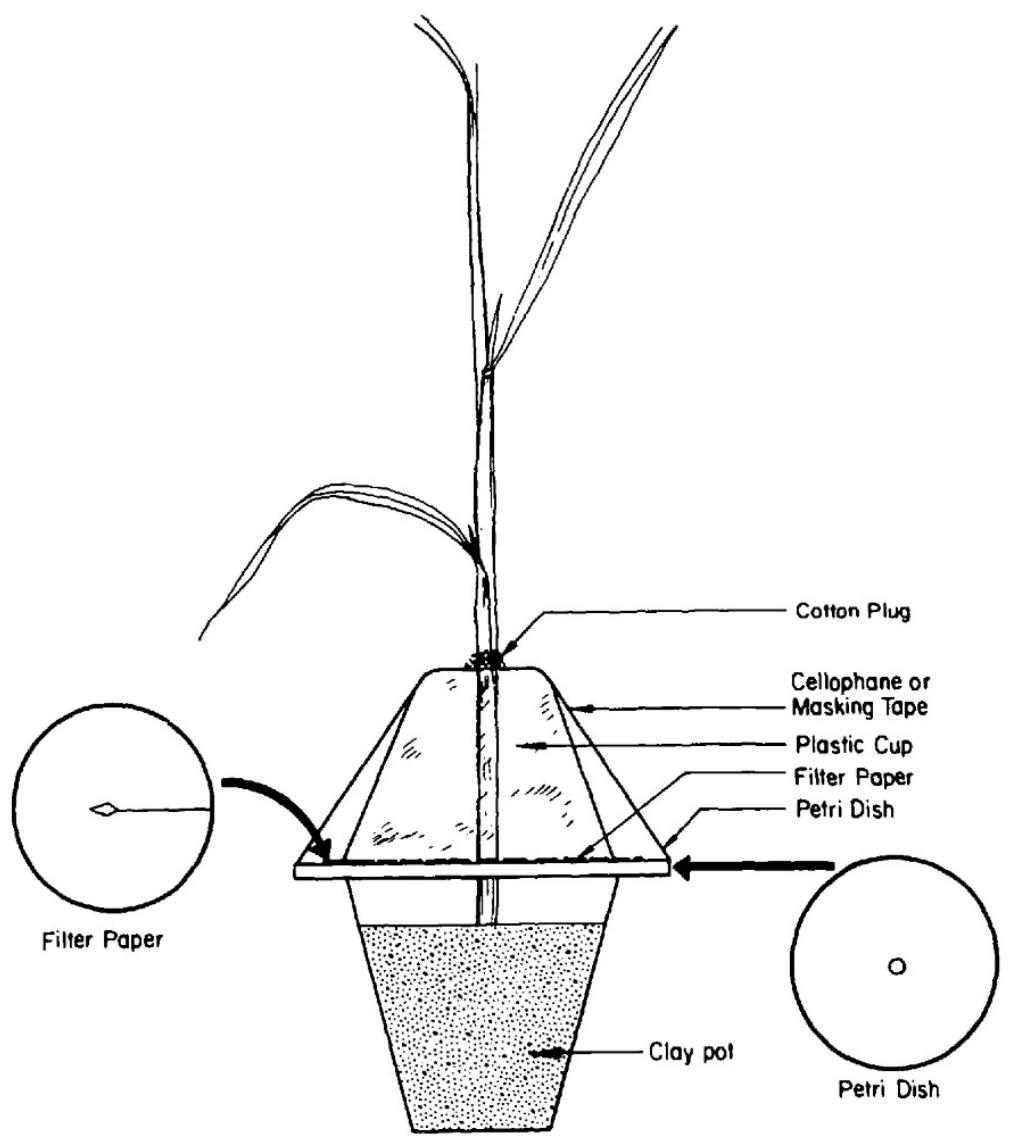

Figure 1. Feeding chamber for N. lugens (Sogawa and Pathak 1970).

Area of Honeydew Spot

To obtain a more exact value for the amount of $N$. lugens excretion, we measured the area of the ninhydrin-positive deposits. The spots were traced on tracing paper, and squares were counted over a millimeter-square graph paper. Experimental design was identical to that described for visual estimates.

In a separate experiment, known honeydew volumes of $1,2,4,8,12,14$, and $18 \mu$ liters were spotted on filter papers, and the corresponding area was measured to determine the linear correlation coefficient $(\mathrm{r})$ and the coefficient of determination $\left(\mathrm{R}^{2}\right)$ of area $\left(\mathrm{mm}^{2}\right)$ on volume ( $\mu$ liters) through a simple linear regression analysis.

\section{Gravimetric Measurements}

Instead of counting the squares occupied by the spot, a tedious procedure, the area of honeydew was expressed gravimetrically. The stained areas were cut out and then weighed in a mg balance. Results are expressed in mg of filter paper containing honeydew deposits. Experimental design was the same as that mentioned in the previous 2 experiments. 
The weights of stained areas produced by known honeydew volumes were obtained to determine $r$ and $R^{2}$ values through a simple linear regression analysis of weight $(\mathrm{mg})$ on volume ( $\mu$ liter) of honeydew as previously mentioned.

Volumetric Method

A slight modification of the feeding chamber as described under Filter Paper Method as developed by Alam (1978) and Iman (1978) was utilized to collect fresh honeydew. Parafilm $\mathrm{M}$ was stretched over the base of the inverted cup, thus sealing the chamber. Five previously starved 2-day-old $N$. lugens females were placed in the chamber through a small hole at the top of the cup. The hole was then sealed with parafilm. The tight seal provided by the parafilm minimized evaporation of the honeydew droplets and made quantification possible. Overnight feeding provided sufficient honeydew droplets on the parafilm for measurement. Calibrated micropipettes of various sizes (1-100 $\mu$ liters) were used to measure the volume of honeydew excreted. Each feeding chamber served as a replicate, and feeding chambers were arranged in a completely randomized design with 3 replications.

\section{Color Intensity Measurement}

Two tests were conducted, one with IR varieties and another with the resistant sources, Mudgo and ASD7. Experimental design in the 1st test was identical to that in the volumetric method except that there were 4 replicates in the 2 nd test. The feeding chamber was the same as previously described except that it did not have to be tightly sealed. Thus, discs cut from ordinary plastic sheets were substituted for the parafilm. Ten $\mu$ liters of distilled water were added to dissolve the dried honeydew deposits. To determine the concentration of amino acids, one $\mu$ liter sample of this solution was streaked on a Whatman No. 50 filter paper strip $(200 \times 25 \mathrm{~mm})$ as a $10 \mathrm{~mm}$ long line across the center, with intervals of 10 $\mathrm{mm}$ between streaks. Filter papers were air-dried and treated with $0.001 \%$ ninhydrin in acetone solution and oven-dried at $100^{\circ} \mathrm{C}$ for $5 \mathrm{~min}$.

Another one- $\mu$ liter sample of the same solution was streaked on a separate filter paper strip, then treated with $2 \%$ aniline hydrochloride in ethyl alcohol and oven-dried for 15$20 \mathrm{~min}$ at $100^{\circ} \mathrm{C}$ for determination of sugar concentration.

Ninhydrin-treated filter papers gave dark to light violet stripes depending on the concentration of amino acids in the honeydew. Aniline-treated papers gave dark to light brown stripes depending on the sugar concentration of the honeydew.

The stain intensity was measured through a Fujiox Densitometer FD-A IV with an opening slit of $1 \times 8 \mathrm{~mm}$, using a yellow filter of $350 \mathrm{~m} \mu$ wavelength. Optical density was adjusted to the darkest color with a maximum light transmission of $80 \%$. The ninhydrin and aniline hydrochloride papers were analyzed separately, and results expressed are the sum of the peak heights $(\mathrm{mm})$ produced by both.

To compare amino acid composition of honeydew collected from susceptible and resistant varieties, a 3- $\mu$ liter sample from the honeydew-water solution was spotted on a Whatman No. 1 filter paper sheet $(250 \times 250 \mathrm{~mm})$, and amino acids were separated through paper chromatography by using the solvent system n-butanol-acetic acid-water (3:1:1). After drying, papers were sprayed with $0.001 \%$ ninhydrin and placed at $100^{\circ} \mathrm{C}$ for $5 \mathrm{~min}$. Qualitative analysis of the separated bands was done by comparing $R_{\mathrm{f}}$ values with standard 
amino acids in $0.1 \mathrm{~N}$ hydrochloric acid solution. An estimate of the quantity in each band was made with the densitometer.

\section{Results and Discussion}

\section{Filter Paper Method}

\section{Visual Estimates}

Figure 2 shows an example of treated filter papers collected from feeding chambers containing different IR varieties with and without known genes for N. lugens resistance (IR8, IR20, IR22, and IR24 with no resistance gene; IR26, IR28, IR29, IR30, and IR34 with resistant Bph 1 gene; IR32, IR36, IR38, IR40, and IR42 with resistant bph 2 gene). As indicated for Biotype 1, the size of the standard honeydew area shows clearly that the feeding rate, which is related to honeydew excretion, is greater on susceptible varieties with no resistance genes than on resistant varieties with Bph 1 and bph 2 genes as indicated by the negligible ninhydrin-positive honeydew deposits. For Biotype 2, honeydew excretion is greater on susceptible varieties with no resistance genes or with the Bph 1 gene varieties whereas Biotype 2 shows less feeding on the resistant bph 2 gene varieties. Biotype 3 females excreted more honeydew on susceptible varieties with no resistance genes or with the bph 2 varieties than they did on the resistant Bph 1 gene varieties. 


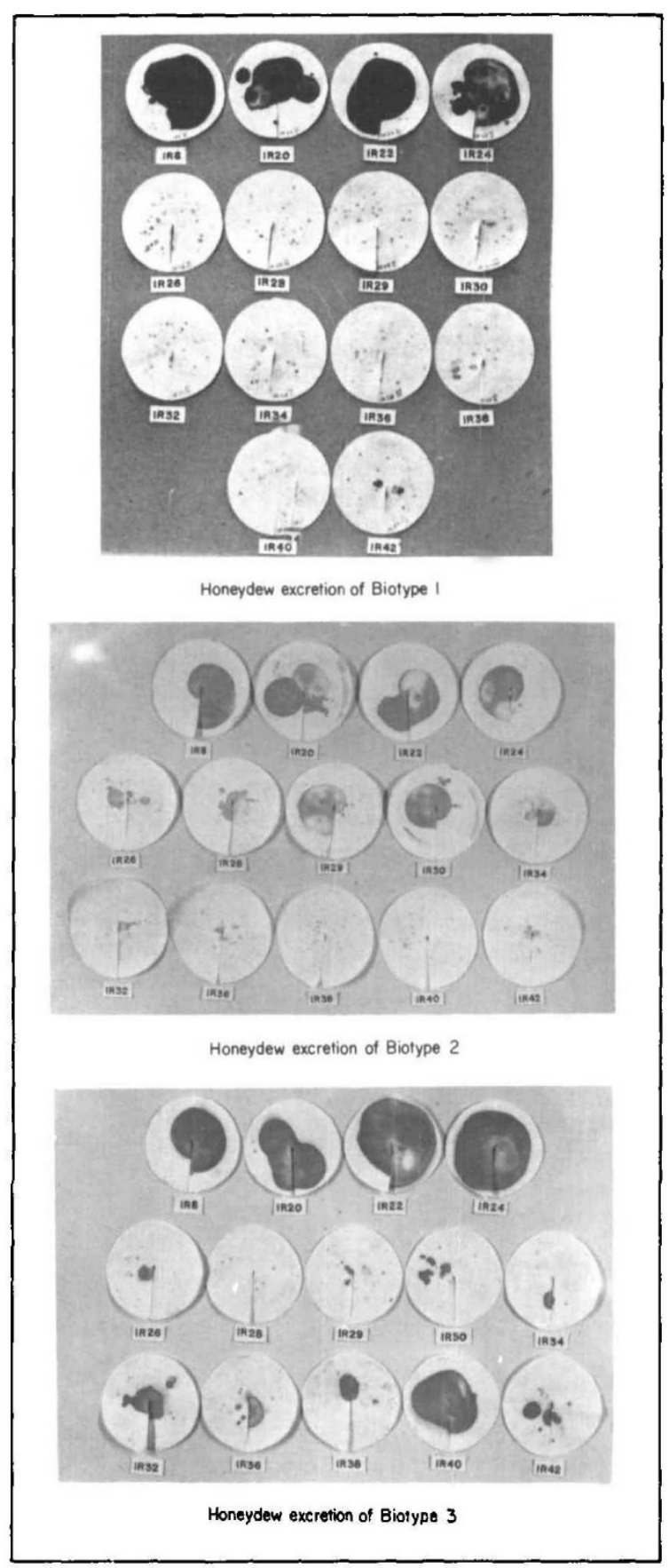

Figure 2. Visual demonstration of honeydew excreted on filter paper by 5 N. lugens Biotypes 1, 2, and 3 female adults on 30-day-old IR variety rice seedlings, IRRI, 1978. 
Area of Honeydew Spots

Table 1 shows the area $\left(\mathrm{mm}^{2}\right)$ of honeydew excreted on filter paper by 5 female adults of Biotypes 1, 2, and 3 when feeding on 30-day-old rice seedlings of TN1, Mudgo, and ASD7. The area of honeydew excreted by Biotype 1 on susceptible TN1, which does not carry any gene for resistance, is statistically greater than on resistant varieties Mudgo and ASD7, containing, respectively, Bph 1 and bph 2 genes. Honeydew excretion of Biotype 2 is relatively more on susceptible varieties TNl and Mudgo than on resistant ASD7. Furthermore, a bigger area of Biotype 3 honeydew deposit is obtained on susceptible varieties $\mathrm{TNl}$ and ASD7 than on the resistant Mudgo.

A simple linear regression analysis of area $\left(\mathrm{mm}^{2}, \mathrm{X}\right)$ on volume $(\mu$ liter, $\hat{Y})$ of honeydew was made and the following equation was obtained: $\hat{Y}=0.476+0.176 X$. Results showed a positive correlation where the $\mathrm{r}$ value was 0.998 and $\mathrm{R}^{2}$ value obtained was 0.998 .

Table 1. Area $\left(\mathrm{mm}^{2}\right)$ of ninhydrin positive honeydew and weight $(\mathrm{mg})$ of filter paper containing honeydew excreted by N. lugens Biotypes 1, 2, and 3 on rice varieties, ${ }^{\text {a }}$ IRRI, 1978

\begin{tabular}{|c|c|c|c|c|c|c|c|}
\hline \multirow[b]{2}{*}{ Variety } & \multirow[b]{2}{*}{ Resistance genes } & \multicolumn{2}{|c|}{ Biotype 1} & \multicolumn{2}{|c|}{ Biotype 2} & \multicolumn{2}{|c|}{ Biotype 3} \\
\hline & & $\mathrm{mm}^{2}$ & $\mathrm{mg}$ & $\mathrm{mm}^{2}$ & $\mathrm{mg}$ & $\mathrm{mm}^{2}$ & $\mathrm{mg}$ \\
\hline TN1 & none & $668 \mathrm{a}$ & $68 \mathrm{a}$ & $838 \mathrm{a}$ & 85 a & 929 a & $90 \mathrm{a}$ \\
\hline Mudgo & Bph 1 & $83 \mathrm{~b}$ & $9 \mathrm{~b}$ & $504 a$ & $50 \mathrm{~b}$ & $74 \mathrm{~b}$ & $11 \mathrm{~b}$ \\
\hline ASD7 & bph 2 & $68 \mathrm{~b}$ & $7 \mathrm{~b}$ & $228 \mathrm{~b}$ & $25 \mathrm{c}$ & $625 a$ & $62 a$ \\
\hline
\end{tabular}

a. In a column, means followed by a common letter are not significantly different at the $5 \%$ level by Duncan's multiple range test.

\section{Gravimetric Measurements}

Results for weight of honeydew (mg) shown in Table 1 indicate the same trends as for area $\left(\mathrm{mm}^{2}\right)$. The weight of filter paper containing honeydew stains of Biotype 1 is greater on TN1 than on varieties Mudgo and ASD7. Values for Biotype 2 are relatively higher on susceptible varieties TN1 and Mudgo than on resistant ASD7. Biotype 3 values are high on TN1 and ASD7 but low on the resistant variety Mudgo.

Similarly, a simple linear regression analysis of weight $(\mathrm{mg}, \mathrm{X})$ on volume $(\mu$ liter, $\hat{Y})$ of honeydew was made and the following equation was obtained: $\hat{Y}=0.754+0.159 X$. The $\mathrm{r}$ value obtained was 0.997 and $\mathrm{R}^{2}, 0.996$.

\section{Volumetric Method}

Table 2 shows the volume of honeydew ( $\mu$ liter) excreted by 5 females of Biotype 1,2, or 3 , which fed overnight on 30-day-old seedlings of various IR varieties. The volume of honeydew excreted on susceptible varieties is greater than that on the resistant varieties. For example, the volume excreted by Biotype 1 is relatively more on the varieties with no resistance gene than on the Bph 1 or bph 2 gene varieties except for 1R34 and IR40, where the volume is less but not statistically different from some of the susceptible varieties, These results are similar to those from greenhouse or field varietal screening against Biotype 1 where IR40 sometimes rates as 7 on a 1-9 scale (where $1=$ resistant and $9=$ susceptible). Honeydew volume of Biotype 2 on the same varieties was generally greater on varieties with no resistance gene or with the Bph 1 gene varieties than on those with the bph 
2 gene. However, volume of honeydew collected from IR38 and IR40, 2 resistant varieties, was not statistically different from the amount obtained from some susceptible varieties. Biotype 3 honeydew volume was greater on the varieties with no resistance gene, but there were no clear differences between the Bph 1 gene and the bph 2 gene varieties, which are, respectively, resistant and susceptible to this Biotype.

Table 2. Volume ( $\mu$ liter) of honeydew excreted by N. lugens Biotypes 1, 2, and 3 feeding on different IR varieties, ${ }^{\text {a }}$ IRRI, 1978

\begin{tabular}{lcccc}
\hline Varieties & Resistance genes & Biotype 1 & Biotype 2 & Biotype 3 \\
\hline IR8 & None & $132 \mathrm{ab}$ & $114 \mathrm{ab}$ & $112 \mathrm{ab}$ \\
IR20 & None & $89 \mathrm{abc}$ & $98 \mathrm{ab}$ & $68 \mathrm{bc}$ \\
IR22 & None & $150 \mathrm{a}$ & $137 \mathrm{a}$ & $149 \mathrm{a}$ \\
IR24 & None & $154 \mathrm{a}$ & $99 \mathrm{ab}$ & $109 \mathrm{ab}$ \\
IR26 & Bph 1 & $27 \mathrm{de}$ & $63 \mathrm{abc}$ & $15 \mathrm{ef}$ \\
IR28 & Bph 1 & $20 \mathrm{e}$ & $67 \mathrm{abc}$ & $7 \mathrm{~g}$ \\
IR29 & Bph 1 & $4 \mathrm{f}$ & $47 \mathrm{abcd}$ & $14 \mathrm{ef}$ \\
IR30 & Bph 1 & $22 \mathrm{e}$ & $90 \mathrm{ab}$ & $23 \mathrm{~d}$ \\
IR32 & bph 2 & $7 \mathrm{f}$ & $19 \mathrm{cde}$ & $17 \mathrm{ef}$ \\
IR34 & Bph 1 & $48 \mathrm{~cd}$ & $21 \mathrm{abc}$ & $13 \mathrm{fg}$ \\
IR36 & bph 2 & $22 \mathrm{e}$ & $32 \mathrm{~d}$ \\
IR38 & bph 2 & $24 \mathrm{de}$ & $26 \mathrm{bcde}$ & $21 \mathrm{def}$ \\
IR40 & bph 2 & $69 \mathrm{bc}$ & $29 \mathrm{bcde}$ & $44 \mathrm{~cd}$ \\
IR42 & bph 2 & $18 \mathrm{e}$ & $15 \mathrm{de}$ & $14 \mathrm{ef}$ \\
\hline
\end{tabular}

a. In a column, means followed by a common letter are not significantly different at the $5 \%$ level by Duncan's multiple range test.

Color Intensity Measurements

Table 3 gives the total color intensity of honeydew treated with ninhydrin and aniline, expressed in densitometer peak heights, of Biotypes 1,2, or 3 feeding on several IR varieties (Test 1 ) and the differential varieties (Test 2 ). Peak heights produced by sugars as indicated by the aniline treated papers were low, and thus the amino acid constituents mostly contributed to the peak heights indicated in Table 3. Large quantities of honeydew, as indicated by high color intensity, were excreted by Biotype 1 only on varieties with no resistance genes and by Biotype 2 on varieties with no resistance gene or those which carry the Bph 1 gene. Large amounts of honeydew were excreted by Biotype 3 on varieties with no resistance gene and on those carrying the bph 2 gene. Auclair (1959) reported that A. pisum feeding on susceptible pea varieties generally excreted honeydew containing a higher concentration of free amino acids and amides than when feeding on resistant varieties. 
Table 3. Color intensity expressed as the sums of the peak heights $(\mathrm{mm})$ of ninhydrin and aniline treated honeydew excreted by N. lugens Biotypes 1, 2, and 3 feeding on different IR varieties, a IRRI, 1978

\begin{tabular}{|c|c|c|c|c|}
\hline Varieties & Resistance genes & Biotype 1 & Biotype 2 & Biotype 3 \\
\hline \multicolumn{5}{|c|}{ Test 1} \\
\hline IR8 & None & $92 \mathrm{a}$ & $51 \mathrm{a}$ & $51 \mathrm{ab}$ \\
\hline IR20 & None & $83 \mathrm{a}$ & $42 \mathrm{a}$ & $51 \mathrm{ab}$ \\
\hline IR22 & None & $99 \mathrm{a}$ & $58 \mathrm{a}$ & $52 \mathrm{ab}$ \\
\hline IR24 & None & 104 a & $46 \mathrm{a}$ & $52 \mathrm{ab}$ \\
\hline IR26 & Bph 1 & $4 \mathrm{c}$ & $41 \mathrm{a}$ & $3 \mathrm{e}$ \\
\hline IR28 & Bph 1 & $0 \mathrm{~d}$ & $41 \mathrm{a}$ & $2 \mathrm{e}$ \\
\hline IR29 & Bph 1 & $0 \mathrm{~d}$ & $31 \mathrm{ab}$ & $17 \mathrm{c}$ \\
\hline IR30 & Bph 1 & $4 \mathrm{c}$ & $48 \mathrm{a}$ & $13 d$ \\
\hline IR32 & bph 2 & $2 \mathrm{c}$ & $0 \mathrm{e}$ & $41 \mathrm{abc}$ \\
\hline IR34 & Bph 1 & c & $56 \mathrm{a}$ & $0 \mathrm{f}$ \\
\hline IR36 & bph 2 & $3 c$ & $3 \mathrm{e}$ & $27 \mathrm{bcd}$ \\
\hline IR38 & bph 2 & $0 \mathrm{~d}$ & $6 \mathrm{~cd}$ & $37 \mathrm{abc}$ \\
\hline IR40 & bph 2 & $2 \mathrm{c}$ & $15 \mathrm{bc}$ & $61 \mathrm{a}$ \\
\hline IR42 & bph 2 & $9 b$ & 2 de & $21 \mathrm{~cd}$ \\
\hline \multicolumn{5}{|c|}{ Test 2} \\
\hline TN1 & None & $59 a$ & $48 \mathrm{a}$ & $44 \mathrm{a}$ \\
\hline Mudgo & Bph 1 & $7 \mathrm{~b}$ & $18 \mathrm{ab}$ & $3 c$ \\
\hline ASD7 & bph 2 & $10 \mathrm{~b}$ & $9 \mathrm{c}$ & $46 \mathrm{a}$ \\
\hline
\end{tabular}

a. In a column, means followed by a common letter are not significantly different at the $5 \%$ level by Duncan's multiple range test.

One-dimensional paper chromatography of $3 \mu$ liters of fresh honeydew excreted by 5 Biotype 1 female adults fed on different IR varieties resulted in the separation of 8 amino acid bands of high color intensity on all susceptible varieties (Fig. 3). High densitometer measurements were obtained particularly on 3 bands, corresponding to the aspartic acid, the glycine-glutamic acid-serine band, and the alanine band on IR8, IR20, IR22, and IR24. However, on resistant varieties IR28, IR32, and IR40, a maximum of only 3 bands were separated, the color intensity of which were very low. Similar results were obtained from Biotype 2 feeding on susceptible varieties IR8, IR26, IR28, and IR34 and on resistant varieties IR38 and IR42. Likewise, high color intensities on different amino acid bands separated from Biotype 3 honeydew collected from susceptible varieties such as IR8, IR20, and IR40 were observed while honeydew from resistant variety IR26 showed only 2 amino acid bands of low color intensities. 


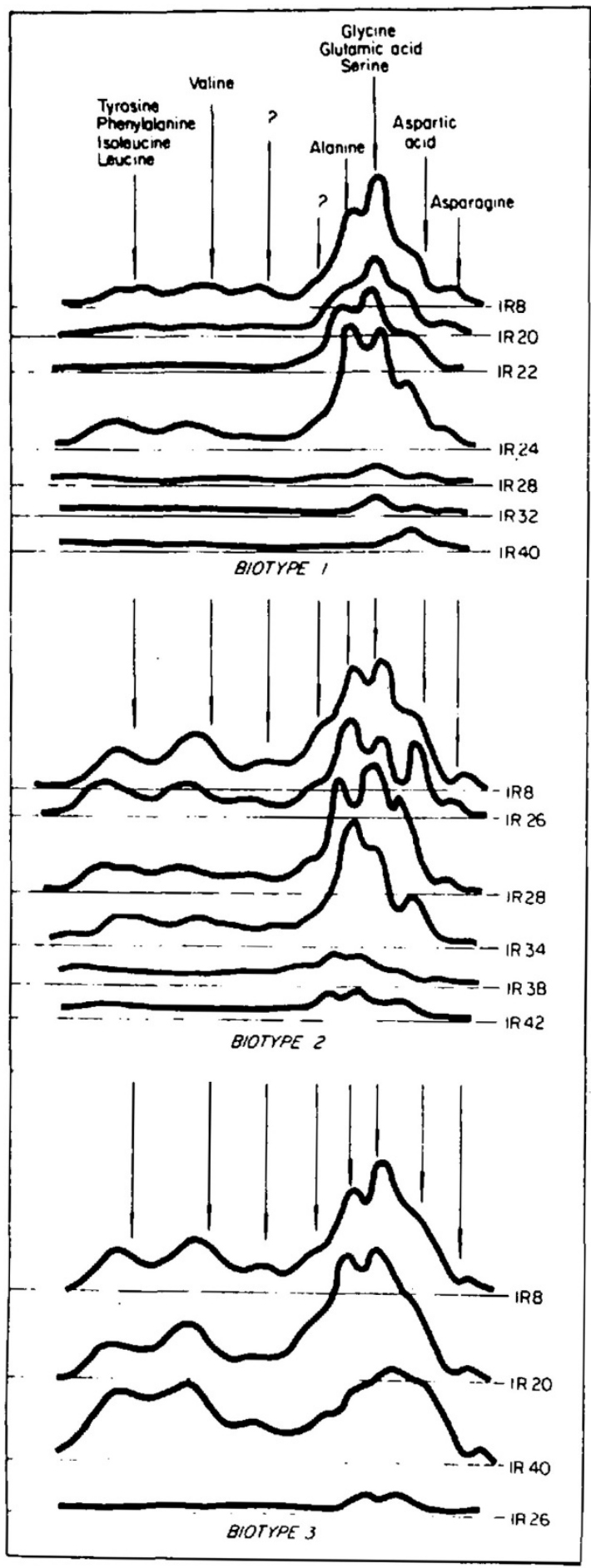

Figure 3. Densitometer readings of separated amino acid bands from honeydew excreted by N. lugens Biotype 1, 2, and 3 feeding on IR rice varieties, IRRI, 1978. 
The fewer amino acid bands detected by paper chromatography of honeydew from hoppers feeding on resistant varieties may be due to the low amino acid concentration in the honeydew excreted. It has previously been demonstrated that the N. lugens Biotypes 1 , 2 , and 3 suck much smaller quantities of plant sap from resistant than susceptible varieties (Karim 1975, Alam 1978, and Iman 1978). It may be that the insect absorbs most of the amino acids present in the small quantities of plant sap ingested when feeding on resistant varieties. Another reason for the few amino acid bands on resistant varieties may be due to the dilution effect of the water on the small amount of honeydew excreted by the insect, the result of which was below the sensitivity of the technique used in this experiment.

The results suggest that brown planthopper honeydew excretion may also be assessed by measuring the color intensity or concentration of its amino acid constituents. Such a study would be relatively simple and may provide basic information on the relationship between feeding activities and the degree of resistance or susceptibility of rice varieties.

Honeydew excretion, although an indirect measure of the feeding rate of brown planthopper, provided a simple yet precise bioassay for studies related to brown planthopper feeding activity. Auclair (1959) found that excretion rates of the pea aphid were highest on susceptible pea plants and concluded that relative aphid feeding can be indirectly estimated by excretion rates. Similar results have been obtained for various rice hoppers, $\mathrm{Ne}$ photettix virescens Ishihara (Cheng 1969), Sogatella furcifera (Horvath) (Rodriguez-Rivera 1972), and Recilia dorsalis (Motschulsky) (Pongprasert 1974). Measurements of area or weight of honeydew on filter papers gave satisfactory results, although the procedure was extremely tedious. Volumetric measurements, however, were less sensitive, as it was difficult to differentiate honeydew droplets from other deposits present on the parafilm, possibly products of plant or insect respiration. Because the concentration of amino acids and sugars in the honeydew of brown planthoppers was related to the degree of feeding, measuring total color intensity of honeydew was the most precise method. However, measuring area of honeydew on filter papers could be satisfactorily used by less equipped laboratories.

Since a differential reaction of brown planthopper Biotypes 1, 2, or 3 on check varieties TN1, Mudgo, and ASD 7 as well as on IR varieties was obtained, honeydew excretion, using any of the aforementioned procedures, provides a suitable bioassay for biotype identification. These described methods can substitute for the time-consuming nymphal survival and population development tests traditionally used in biotype identification, and they are useful in the final screening for resistant and moderately resistant rice varieties.

\section{Notes}

1. Homoptera: Delphacidae.

2. Submitted for publication Jan. 15, 1979.

3. Senior Research Assistant, Director of Research and Training Coordination, and Entomologist, respectively, The International Rice Research Institute, P. O. Box 933, Manila, Philippines. 


\section{References Cited}

Alam, M. D. 1978. Resistance to biotype 3 of the brown planthopper Nilaparvata lugens (Stål) in rice varieties. M.S. thesis. University of the Philippines at Los Baños. 108 pp.

Auclair, J. L. 1958. Honeydew excretion in the pea aphid Acyrthosiphon pisum (Harr.). J. Insect Physiol. 2: 330-7.

- 1959. Feeding and excretion by the pea aphid Acyrthosiphon pisum (Harr.). (Homoptera: Aphididae) reared on different varieties of peas. Entomol. Exp. Appl. 2: 279-86.

Cheng, C. H. 1969. Biological interrelationships between Nephotellix impicticeps Ishihara and some resistant and susceptible rice varieties. M.S. thesis. University of the Philippines at Los Baños. $117 \mathrm{pp}$.

Dyck, V. A. 1979. The brown planthopper problem. P. 3-17. In International Rice Research Institute, The Brown Planthopper: Threat to Rice Production in Asia. Los Baños, Philippines. 369 pp.

Iman, M. 1978. Resistance of rice varieties to biotype 2 of the brown planthopper, Nilaparvata lugens (Stål). Ph.D. thesis. University of the Philippines at Los Baños. 110 pp.

Karim, A. N. M. R. 1975. Resistance to the brown planthopper, Nilaparvata lugens (Stål) in rice varieties. M.S. thesis. University of the Philippines at Los Baños. 131 pp.

Khush, G. S. 1979. Genetics and breeding for resistance to the brown planthopper. P. 321-32. In International Rice Research Institute, The Brown Planthopper: Threat to Rice Production in Asia. Los Baños, Philippines. 369 pp.

Ling, K. C., V. M. Aguiero, and S. H. Lee. 1970. A mass screening method for testing resistance to grassy stunt disease of rice. Plant Dis. Rep. 54: 565-69.

Ling, K. C., E. R. Tiongco, and V. M. Aguiero. 1978. Rice ragged stunt, a new virus disease. Ibid. 62: 701-5.

Pathak, M. D., and G. S. Khush. 1979. Studies on varietal resistance in rice to the brown planthopper at the International Rice Research institute. P. 285-301. In International Rice Research institute, The Brown Planthopper: Threat to Rice Production in Asia. Los Baños, Philippines. 369 pp.

Pongprasert, S. 1974. Resistance to the zigzag leafhopper, Recilia dorsalis (Motschulsky), in rice varieties. M.S. thesis, University of the Philippines at Los Baños. 76 pp.

Rodriguez-Rivera, R. 1972. Resistance to the whitebacked planthopper, Sogatella furcifera (Horvath), in rice varieties. M.S. thesis. University of the Philippines at Los Baños. 69 pp.

Sogawa, K., and M. D. Pathak. 1970. Mechanism of brown planthopper resistance in Mudgo variety of rice (Hemiptera: Delphacidae). Appl. Entomol. Zool. 5: 145-58. 